Sādhanā Vol. 36, Part 3, June 2011, pp. 393-410. (c) Indian Academy of Sciences

\title{
Evaluation of size dependent design shear strength of reinforced concrete beams without web reinforcement
}

\author{
G APPA RAO ${ }^{1,2, *}$ and S S INJAGANERI ${ }^{1}$ \\ ${ }^{1}$ Department of Civil Engineering, Indian Institute of Technology Madras, Chennai \\ 600036 , India \\ ${ }^{2}$ IWB, University of Stuttgart, Pfaffenwaldring 4, 70569 Stuttgart, Germany \\ e-mail: garao@iitm.ac.in
}

MS received 3 July 2009; revised 17 February 2011; accepted 23 April 2011

\begin{abstract}
Analytical studies on the effect of depth of beam and several parameters on the shear strength of reinforced concrete beams are reported. A large data base available has been segregated and a nonlinear regression analysis (NLRA) has been performed for developing the refined design models for both, the cracking and the ultimate shear strengths of reinforced concrete (RC) beams without web reinforcement. The shear strength of RC beams is size dependent, which needs to be evaluated and incorporated in the appropriate size effect models. The proposed models are functions of compressive strength of concrete, percentage of flexural reinforcement and depth of beam. The structural brittleness of large size beams seems to be severe compared with highly ductile small size beams at a given quantity of flexural reinforcement. The proposed models have been validated with the existing popular models as well as with the design code provisions.
\end{abstract}

Keywords. CE database; size effect; cracking strength; shear strength; code provisions; modelling.

\section{Introduction}

Many reinforced concrete structural elements such as slabs, footings and joists are constructed without shear reinforcement (ASCE-ACI 445 Committee 1998). Numerous experimental efforts made on reinforced concrete (RC) beams under concentrated loads showed that the shear strength decreases with increase in the beam depth. The reinforced concrete beams are classified into three types depending on the a/d ratios (maintaining the compressive strength of concrete, percentage of flexural reinforcement and depth of the beam constant) as (i) deep beams with 0 $<\mathrm{a} / \mathrm{d} \leq 1$, (ii) short beams with $1<\mathrm{a} / \mathrm{d} \leq 2.5$, and (iii) normal beams with $\mathrm{a} / \mathrm{d}>2.5$ (Bresler \&

*For correspondence 
MacGregor 1967). For these a/d ratios, the failure mechanisms in RC beams are well-understood. Till today, though several models have been proposed to estimate the shear strength of RC beams, their applicability is limited to a particular class of beams only. The safety margins on the shear strength of beams vary with depth. In order to establish the uniform safety margins on the shear strength of RC beams, a large experimental data base needs to be made available or needs to be generated using a strong nonlinear FE analysis. In this study, a large number of reports have been reviewed for generating the reliable data on the shear strength of $\mathrm{RC}$ beams.

From the lessons learnt from the failure of Wilkins Air Force Department Warehouse in Shelby, Ohio in 1955, the design provisions existing at that time were verified. Subsequently, modifications to the ACI 318 provisions for the design of RC beams for shear based on the diagonal shear strength were proposed (ACI-ASCE 326 Committee 1962). The catastrophic shear failures of RC structures, during Hyogo-Ken Nanbu earth quake, Kobe in 1995 further attributed to the development of the size dependent models on the shear strength in the codes of practice (Maekawa et al 2003). The recent research efforts have revealed that the shear strength provisions for high strength concrete beams need to be re-established with size dependent forms.

\section{Review of literature}

As reported by the ACI-ASCE Committee, based on the review of several models, the shear strength of RC beams depends on the strength of concrete, the percentage of the longitudinal reinforcement and the span-to-depth ratio or stiffness of the beam. Clark (1951) reported that the nominal shear strength of RC beam is a function of the compressive strength of concrete, the percentage of the longitudinal reinforcement and the shear span-to-depth ratio. The extensive experimental investigations by Kani (1967) showed very strong size effect on the shear strength on $\mathrm{RC}$ beams without web reinforcement. It has been reported that a reduction of strength of beams up to about $40 \%$ was observed as the depth of the beam increased from $150 \mathrm{~mm}$ to 1200 $\mathrm{mm}$. The size effect observed in Kani's experiments on the large size beams was assumed to be due to large beam depth-to-breadth ratios (Taylor 1972). The experimental studies on slender RC deep beams at different depth-to-thickness ratios varying between 25 and 67 demonstrate that the failure of the beams was strongly dependent on eccentricity of the loading (Kong et al 1986).

A size effect model was proposed for the ultimate shear strength of RC beams (Bazant \& Kim 1984), which was later modified by incorporating the size of aggregate (Bazant \& Sun 1987). It was reported that the size effect on the ultimate shear strength of RC beams was strong, while it is not-negligible on the diagonal cracking strength of geometrically similar RC beams in the size range of 1:16 (Bazant \& Kazemi 1991). Similar observations have been reported on the shear strength of deep beams when the shear span-to-depth ratio was 1.0 (Tan \& Lu 1999; Walraven \& Lehwalter 1994). The complex stress distribution in the dowel splitting region of the beams without shear reinforcement still remains empirical (Chana 1987). The high strength concrete beams are sensitive to the size effect. The reduction of the ultimate shear strength is associated with the maximum spacing of the horizontal layers of the reinforcement rather than on the overall depth of the beam (Collins \& Kuchma 1999). The analytical studies on the ultimate shear strength revealed the size effect, which is the product of the ratio of the neutral axis depthto-effective depth of the beam, and the splitting tensile strength of concrete (Zararis \& Papadakis 2001). In HSC deep beams, a strong size effect has been pronounced at small a/h ratios (Yang et al 2003). 


\section{Research significance}

The shear strength of RC beams without web reinforcement appears to be affected by the beam depth and the shear span-to-depth ratio along with other influencing parameters. Despite a reasonable consensus on the existence of size effect on the shear strength of RC beams, there still seems some prejudices and lack of authenticity on the size effect to be proposed for the design in the codes of practice. A review and analysis of the selected reliable experimental data reported in the literature till date has been performed, which proves to be adequate enough to consider the size effect on the design shear strength of RC beams. Two simple models have been proposed to predict the diagonal cracking strength and the ultimate shear strength of RC beams incorporating all the influencing parameters including the beam depth.

\section{Size effect in reinforced concrete}

Two important models are widely recognised for estimating the size dependent shear strength of RC beams (Bazant \& Sun 1987; Niwa et al 1987). It is understood that the shear strength decreases asymptotically as the beam depth increases, in geometrically similar RC beams. The causes of the size effect in RC beams could be attributed to the (i) material heterogeneity, and (ii) discontinuity of flow of stress (Karihaloo 1995). According to the Weibull's weak link theory, the strength of a structure is inversely proportional to its volume. This statistical strength theory cannot be applicable to concrete structures unless the failure occurs at the initiation of cracking (Bazant \& Kazemi 1991). Hence, there is a need for an appropriate size effect law for predicting the design shear strength of practical range of sizes of RC structures. Such model should ensure prediction of actual shear strength and estimation of uniform safety margins on the ultimate shear strength with different sizes of beams.

\section{Review of existing models}

When the ultimate strength and the diagonal cracking strength of $\mathrm{RC}$ beams are equal, the size effect in such beams is non-existent. The fracture mechanics based size effect is related to the non-simultaneous or propagating type of failure as seen in the short and deep beams, which are associated with the ultimate shear strength (Bazant \& Kazemi 1991). The ultimate shear strength of RC beams incorporating the beam depth by Bazant \& Kim (1984) is as follows

$$
v_{u}=\frac{10 \rho^{1 / 3}}{\sqrt{1+\frac{\mathrm{d}}{25 \mathrm{~d}_{\mathrm{a}}}}}\left(0.083 \sqrt{f_{c}^{\prime}}+20.69 \sqrt{\frac{\rho}{(\mathrm{a} / \mathrm{d})^{5}}}\right), \mathrm{MPa} .
$$

The above model has been further modified by incorporating the size of coarse aggregate (Bazant \& Sun 1987), as below.

$$
v_{u}=\left(0.54 \rho^{1 / 3}\right) \frac{1+\sqrt{\frac{5.08}{\mathrm{~d}_{\mathrm{a}}}}}{\sqrt{1+\frac{\mathrm{d}}{25 \mathrm{~d}_{\mathrm{a}}}}}\left(\sqrt{f_{c}^{\prime}}+249.2 \sqrt{\frac{\rho}{(\mathrm{a} / \mathrm{d})^{5}}}\right), \mathrm{MPa} .
$$

In most of the cases, the onset of formation of first diagonal crack was by visual observations; while in some other cases it was the diagonal crack crossing the mid-height of the beam 
(Pendyala \& Mendis 2000). However, there appears some discrepancies in the observations while interpreting the diagonal cracking. The first empirical model for estimating the diagonal cracking strength of normal beams was by Zsutty (1968) based on the data base available without considering the beam depth into account. Subsequently, many models have been reported on the diagonal cracking strength of RC beams.

An important model on the diagonal strength of RC beams has been proposed by Niwa et al (1987), as below

$$
v_{c r}=1.125 \frac{\rho^{1 / 3}}{d^{1 / 4}}\left(\mathrm{f}_{\mathrm{c}}^{\prime}\right)^{1 / 3}\left(0.75+\frac{1.4}{\mathrm{a} / \mathrm{d}}\right), \mathrm{MPa}
$$

where

$\mathrm{d}=$ depth of beam, mm, $\rho=$ percentage of beam longitudinal reinforcement, and, $\mathrm{f}_{\mathrm{c}}=$ compressive strength of concrete, $\mathrm{MPa}$

Several codes (CSA 1994; BS 1997; JSCE 1986) adopted a depth factor for estimating the shear strength of RC beams. However, the current ACI code (ACI 318) base its designs on the diagonal cracking strength of the normal strength concrete (NSC) beams, with the depth less than about $400 \mathrm{~mm}$, without considering the influence of beam size.

The design shear strength of RC beams as per ACI 318 M-05 (2005) is as follows,

$$
\begin{aligned}
& v_{c}=\frac{1}{7}\left(\sqrt{f_{c}^{\prime}}+120 \rho \frac{\mathrm{V}_{\mathrm{u}} \mathrm{d}}{\mathrm{M}_{\mathrm{u}}}\right) \leq 0.3 \sqrt{f_{c}^{\prime}}, \mathrm{MPa}, \\
& \text { where } \quad \frac{\mathrm{V}_{\mathrm{u}} \mathrm{d}}{\mathrm{M}_{\mathrm{u}}} \leq 1.0 .
\end{aligned}
$$

Equation 4 overestimates the shear strength of the concrete in the uncracked portion, while the contribution of the longitudinal reinforcement and the effect of the ratio $V_{u} / M_{u} d$ are underestimated (ACI 318 2002).

According to the British code (BS 8110 1997), the beam depth has been included for $\mathrm{a} / \mathrm{d}>2$. The nominal shear strength of the beam is as follows

$$
\begin{gathered}
v_{\mathrm{c}}=\frac{0.79}{\gamma_{\mathrm{m}}}\left(\frac{100 A_{s}}{b_{v} d}\right)^{1 / 3}\left(\frac{400}{d}\right)^{1 / 4}\left(\frac{f_{c u}}{25}\right)^{1 / 3} \mathrm{MPa}, \\
v_{c}=(\text { Eqn. } 8)\left(2 \frac{\mathrm{d}}{\mathrm{a}_{\mathrm{v}}}\right) \text { for } \mathrm{a} / d<2.0,
\end{gathered}
$$

where $\frac{100 A_{s}}{b_{v} d} \leq 3.0 \quad \frac{400}{d} \geq 1.0 \quad \gamma_{\mathrm{m}}=1.25$ and $\mathrm{f}_{\mathrm{cu}} \leq 40.0 \mathrm{MPa}$.

However, the drawback is that the depth of beam is limited to only $400 \mathrm{~mm}$ through the limit $(400 / \mathrm{d}) \geq 1.0$ with compressive strength of concrete is less than or equal to $40 \mathrm{MPa}$ and the percentage of the flexural reinforcement is $3.0 \%$.

\section{Present refined models}

In order to develop the design models for predicting the diagonal cracking strength and the ultimate shear strength of the beams, the factors influencing the shear strength are identified in their practical ranges. The factors influencing the shear strength of reinforced concrete beams include; (i) compressive strength of concrete, $\mathrm{f}_{\mathrm{c}}^{\prime}$, (ii) percentage of the longitudinal reinforcement, $\rho$, (iii) shear span-to-depth ratio, a/d and (iv) depth of the beam, $d$. The influence of the size of the 
aggregate is ignored as its influence between 8 and $32 \mathrm{~mm}$ has no significant effect (Walraven \& Lehwalter 1994).

For the development of models, nonlinear regression analysis was adopted. From the data available in the literature, 612 reliable data set points were selected for the ultimate shear strength, and 269 data sets for the diagonal cracking strength. The details of the data selected are shown in Appendix I. The effect of various influencing parameters has been understood by plotting the relationship between the shear strength and the individual parameter. From the observations, the exponentials with the individual parameters have been considered. For developing the final form of the model in the present study, the effect of individual influencing parameter i.e., the exponentials such as $\mathrm{k}_{1}, \mathrm{k}_{2}, \mathrm{k}_{3}$, etc., to the individual parameters was maintained as obtained from the observed trend for determining the appropriate coefficients. When the data on high strength concrete beams is incorporated, the shear strength is proportional to the cubic root of the compressive strength of concrete, ${ }^{3} \sqrt{ } \mathrm{f}_{\mathrm{c}}^{\prime}$ rather than the square root, $\sqrt{ } \mathrm{f}_{\mathrm{c}}^{\prime}$. This is reflected in the ACI 318 (2005) provisions indicating that Eq. 4 overestimates the shear strength of concrete. The enhancement of shear strength of short beams beyond the cracking is about 5 times its diagonal cracking strength. The most important factor influencing the shear strength of the beams is the shear span-to-depth ratio. From the observations on the influence of the individual parameters, the forms of the shear strength models are as follows,

$$
\begin{gathered}
\mathrm{v}_{\mathrm{u}}=\left(\mathrm{A}+\frac{\mathrm{B}}{(\mathrm{a} / \mathrm{d})^{k_{1}}}\right)\left[\mathrm{f}_{\mathrm{c}}^{\mathrm{k}_{2}} \rho^{\mathrm{k}_{3}} \mathrm{~d}^{\mathrm{k}_{4}}\right], \\
v_{c r}=\left(\mathrm{C}(\mathrm{a} / \mathrm{d})^{\mathrm{k}_{5}}+\frac{\mathrm{D}}{(\mathrm{a} / \mathrm{d})^{k_{6}}}\right)\left[\mathrm{f}_{\mathrm{c}}^{\mathrm{k}_{7}} \rho^{\mathrm{k}_{8}} \mathrm{~d}^{\mathrm{k}_{9}}\right] .
\end{gathered}
$$

The exponential coefficients from $\mathrm{k}_{2}$ to $\mathrm{k}_{4}$, and $\mathrm{k}_{7}$ to $\mathrm{k}_{9}$ were refined by suitably modulating them to match well with the experimental data, from the rigorous parametric study. The coefficients $\mathrm{A}, \mathrm{B}, \mathrm{C}, \mathrm{D}$, and the exponential coefficients $\mathrm{k}_{1}, \mathrm{k}_{5}$ and $\mathrm{k}_{6}$ were obtained to best fit in the final forms of the models in the following equations,

$$
\begin{gathered}
v_{\mathrm{u}}=\left(0.56+\frac{4.0}{(\mathrm{a} / \mathrm{d})^{3 / 2}}\right)\left[\mathrm{f}^{\prime /} \mathrm{c}^{3} \rho^{1 / 2} \mathrm{~d}^{-1 / 4}\right], \mathrm{MPa}, \\
v_{c r}=\left(0.28 \sqrt[3]{(\mathrm{a} / \mathrm{d})}+\frac{2.0}{(\mathrm{a} / \mathrm{d})^{7 / 6}}\right)\left[\mathrm{f}^{\prime / 3} \rho^{1 / 3} \mathrm{~d}^{-1 / 4}\right], \mathrm{MPa} .
\end{gathered}
$$

Alternatively, the diagonal cracking strength can be expressed in the following form

$$
v_{c r}=v_{\mathrm{u}} \frac{\sqrt[3]{a / d}}{2 \rho^{1 / 6}} .
$$

The $\mathrm{a} / \mathrm{d}$ ratio is replaced with $(\mathrm{M} / \mathrm{Vd})$ ratio, in a beam subjected to uniformly distributed loading, where $\mathrm{M}$ and $\mathrm{V}$ are the bending moment and the shear force at the critical section. It is understood from the basic shear mechanism that the shear strength of RC beams is contributed from the uncracked concrete in compression, aggregate friction along the diagonal cracked plane and dowel action of the longitudinal reinforcement. As soon as the diagonal cracking is formed, with further loading, the additional strength up to the ultimate stage could be ensured by the dowel action of the longitudinal reinforcement embedded in concrete in the tension face of the beam. 
Table 1. Summary of NLRA for ultimate and diagonal cracking strength.

\begin{tabular}{|c|c|c|c|c|c|c|}
\hline \multirow[b]{2}{*}{ Source } & \multicolumn{3}{|c|}{ Ultimate strength } & \multicolumn{3}{|c|}{ Diagonal cracking strength } \\
\hline & $\begin{array}{l}\text { Deg. of } \\
\text { freedom }\end{array}$ & $\begin{array}{l}\text { Sum of } \\
\text { squares }\end{array}$ & $\begin{array}{c}\text { Mean } \\
\text { squares }\end{array}$ & $\begin{array}{l}\text { Degrees of } \\
\text { freedom }\end{array}$ & $\begin{array}{l}\text { Sum of } \\
\text { squares }\end{array}$ & $\begin{array}{c}\text { Mean } \\
\text { squares }\end{array}$ \\
\hline Regression & 2 & 4658.62 & 2329.31 & 2 & 970.76 & 485.38 \\
\hline Residual & 610 & 475.97 & 0.78 & 267 & 65.39 & 0.245 \\
\hline Uncorrected total & 612 & 5134.60 & & 269 & 1036.15 & \\
\hline (Corrected total) & 611 & 2441.90 & & 268 & 198.02 & \\
\hline $\mathrm{R}^{2}$ & & 0.805 & & & 0.67 & \\
\hline F-static & & 2986.3 & & & 1981.1 & \\
\hline Prob $>$ F & & 0.0001 & & & 0.0001 & \\
\hline
\end{tabular}

It may be assumed that in Eqs. 8 and 9, the dowel action of the longitudinal reinforcement may cause the overestimation of the ultimate shear strength. Before diagonal cracking, the dowel action of the longitudinal reinforcement is not expected to be significant. The cubic root variation of the flexural reinforcement ratio seems to be appropriate on the diagonal cracking strength.

The summary of the analysis is reported in table 1 . The values of ' $F$ ' and 'Prob ( $F)$ ' test the overall significance of the regression model. A low value of 0.0001 for 'Prob (F)' indicates that the independent variables are not purely random with respect to the dependent variable. Also, the coefficient of determination is 0.80 for the ultimate shear strength, and 0.67 for the diagonal cracking strength. The scatter of the results for the ultimate shear strength is better than that of the diagonal cracking strength. Therefore, it looks more appropriate to base the design of RC beams on the ultimate strength rather than on the diagonal cracking strength. Further, uniform safety margins can be set for different sizes on the ultimate strength.

\section{Results and discussion}

Figures 1a-i show the variation of the normalised ultimate shear strength by the compressive strength of concrete with the beam depth, as per the earlier models, and also by the codes of practice. The appropriate partial safety factors were imposed on the shear strength proposed in the codes of practice. The comparison of the calculated shear strength of the beams is shown in table 2. The RMSE for the beams with a/d = 1, by Kani (1966) was 0.633* (*over estimation), estimated from Eq. 2 against 0.528 from the present model, Eq. 8. Similarly, for a/d $<1.0$, Eq. 2 overestimates the ultimate shear strength, whereas Eq. 3 predicts reasonably well the diagonal cracking strength of the normal beams. However, the shear strength of the short and deep beams is underestimated. The proposed models in Eqs. 8 and 9, show a fair degree of prediction of both the ultimate and diagonal cracking strengths. The low RMSE with the present models show better correlation with the data in table 2, and in figures 1a-i.

The ACI code underestimates the shear strength on the small size beams with the $\mathrm{a} / \mathrm{d}$ ratios between 1.0 and 2.5 as shown in figures $1 \mathrm{~b}$ and $\mathrm{c}$, and overestimates on the large size HSC beams as shown in figure 1(i). The measured ultimate shear strength and the estimated strengths as per the refined model, in Eqs. 8 and 2, and also predicted by the ACI code are shown in figures $2 \mathrm{~b}$ and $\mathrm{c}$. The shear strength of the beams evaluated by the ACI code provisions are shown in figures $2 \mathrm{a}$ and $\mathrm{d}$ respectively. The correlation coefficient ( $\mathrm{r}$ ) evaluated from the ACI code, Eq. 2, is 0.794 , and on the proposed model is 0.91 . 


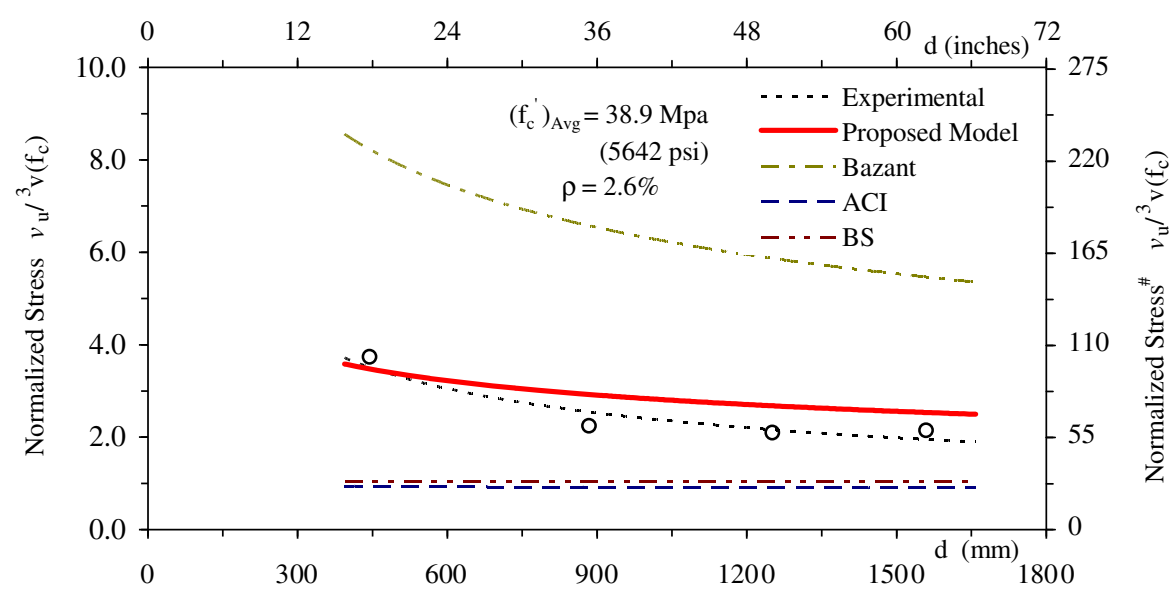

(a) Normalized Stress $v_{\mathrm{u}} / /^{3} \mathbf{v}\left(\mathrm{f}_{\mathrm{c}}\right) \mathrm{v} / \mathrm{s}$ depth $\quad$ TAN-LU ${ }^{12}[\mathrm{a} / \mathrm{d}=0.56]$

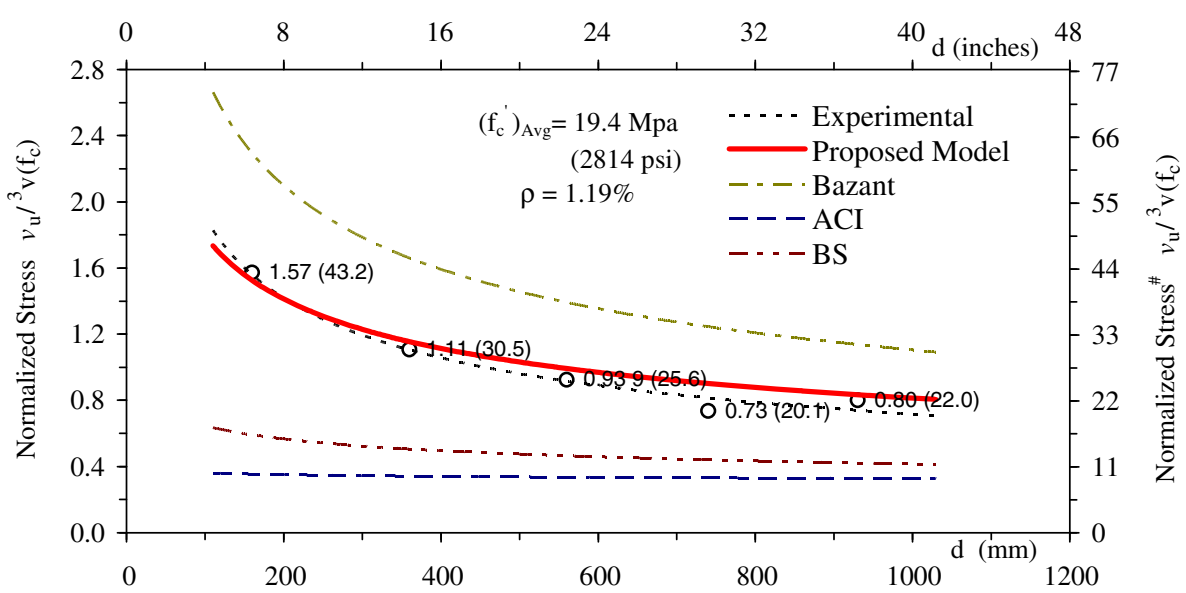

(b) Normalized Stress $v_{u} /{ }^{3} v\left(f_{c}\right) v / s$ depth WALRAVEN ${ }^{13}[\mathrm{a} / \mathrm{d}=1]$

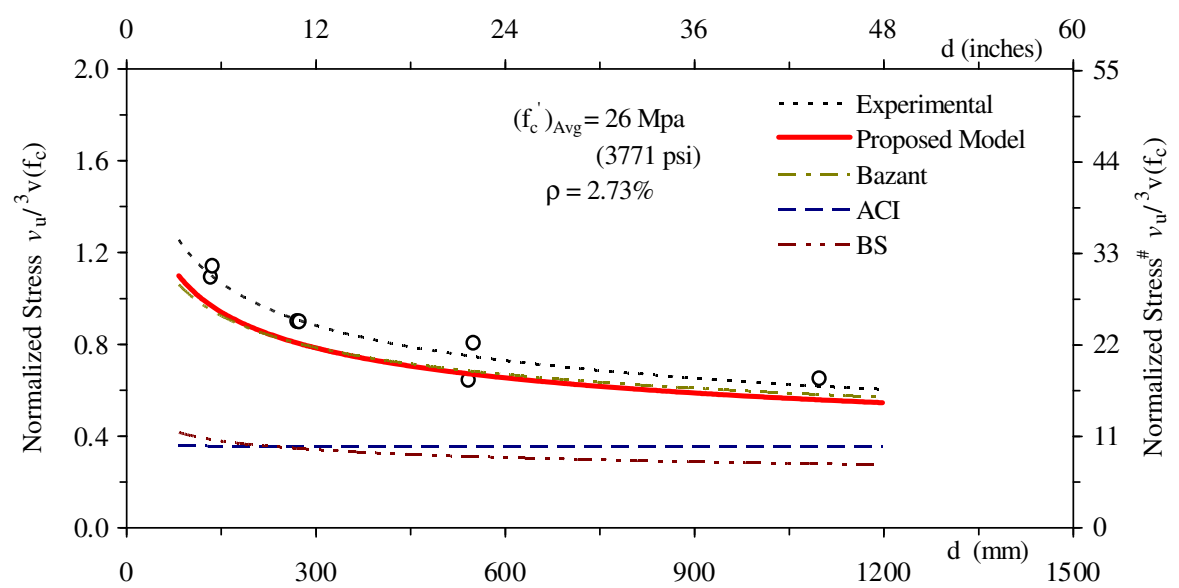

(c) Normalized Stress $v_{\mathrm{u}} /{ }^{3} \mathbf{v}\left(\mathbf{f}_{\mathrm{c}}\right) \mathbf{v} / \mathrm{s}$ depth $\mathrm{KANI}^{6}[\mathrm{a} / \mathrm{d}=2]$

Figure 1. Comparison of $v_{u} /{ }^{3} \sqrt{ } \mathrm{f}_{\mathrm{c}}$ with depth. 


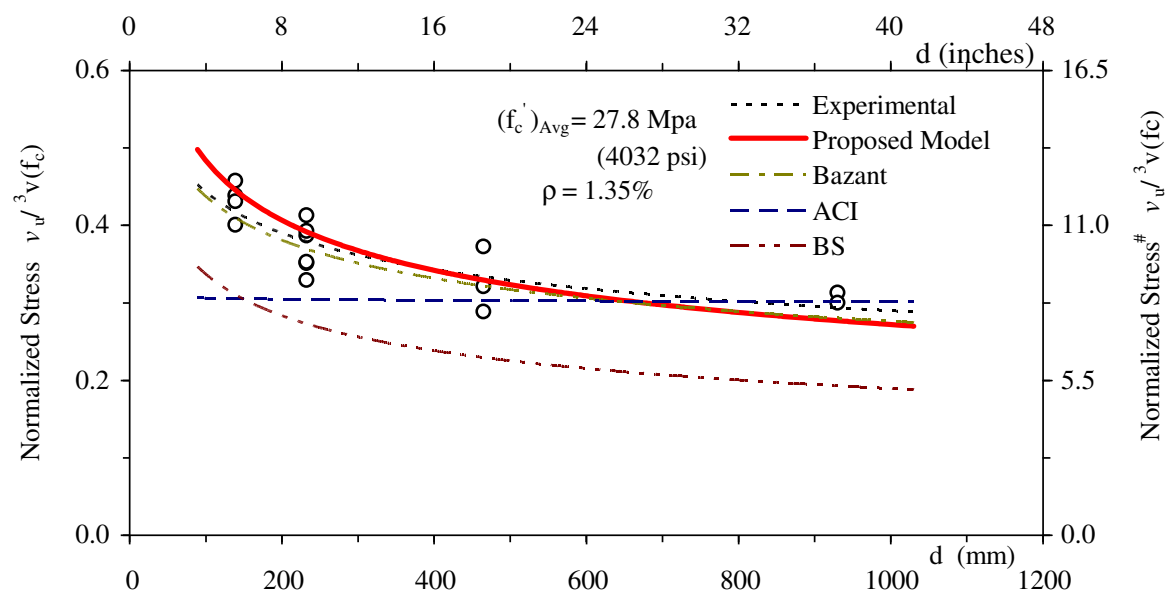

(d) Normalized Stress $v_{u} / I^{3} \mathbf{v}\left(f_{c}\right) v / s$ depth TAYLOR ${ }^{7}[a / d=3]$

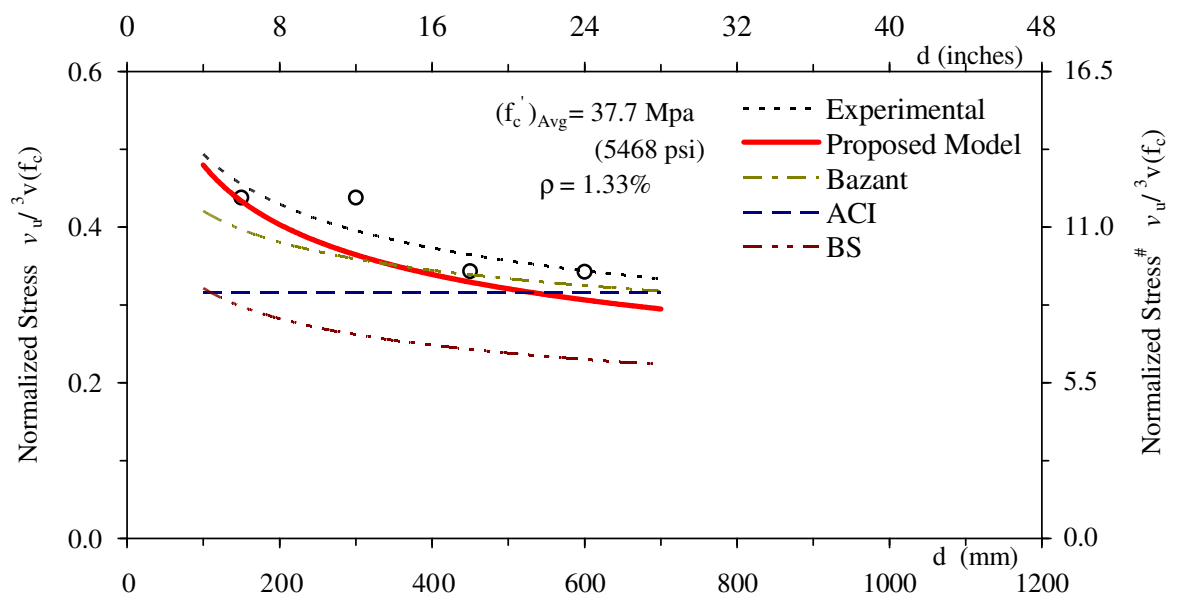

(e) Normalized Stress $v_{u} / I^{3} \mathbf{v}\left(f_{c}\right) v / s$ depth LEONHARDT ${ }^{+}[a / d=3]$

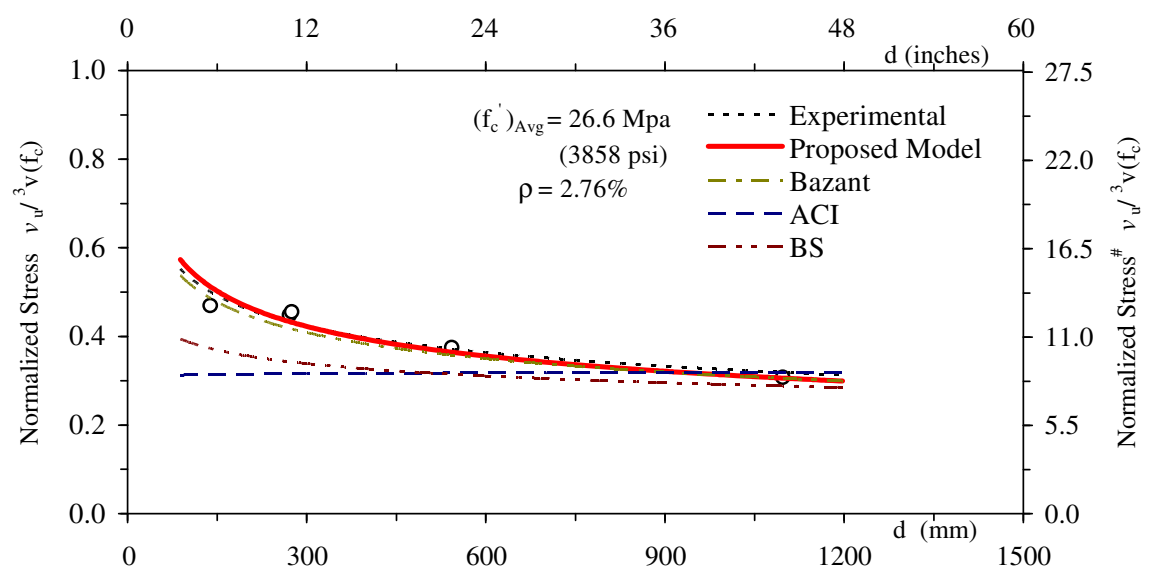

(f) Normalized Stress $v_{\mathrm{u}} /{ }^{3} \mathbf{v}\left(\mathrm{f}_{\mathrm{c}}\right)$ v/s $\operatorname{depth} \mathrm{KANI}^{6}[\mathrm{a} / \mathrm{d}=4]$

Figure 1. (continued). 


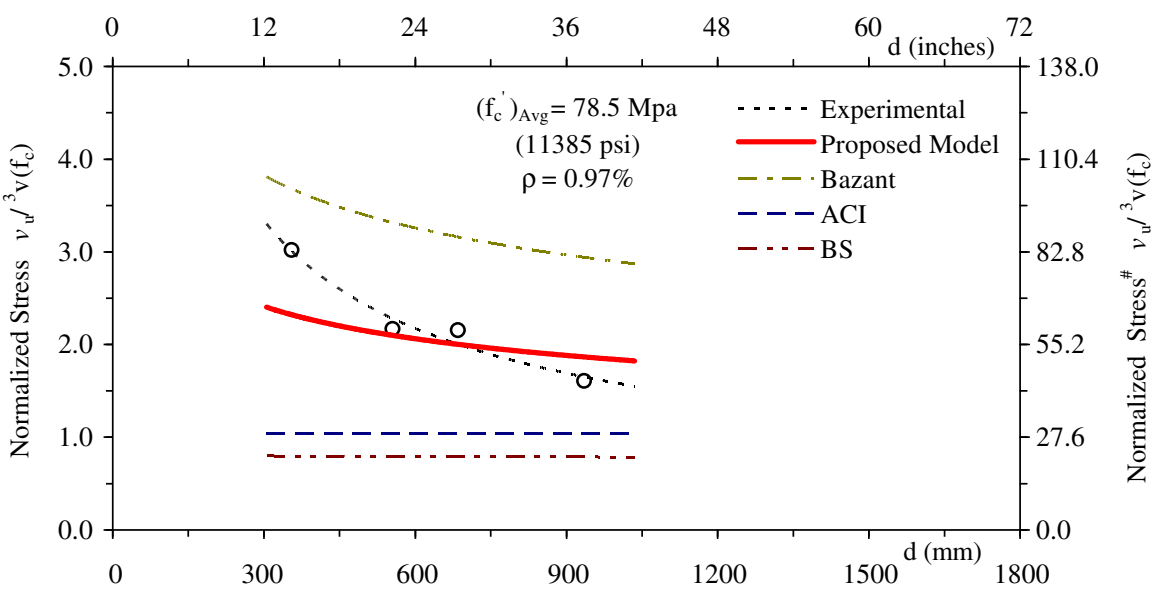

(g) Normalized Stress $v_{\mathrm{u}} / /^{3} \mathbf{v}\left(\mathbf{f}_{\mathrm{c}}\right) \quad \mathrm{v} / \mathrm{s}$ depth YANG et.al ${ }^{17}[\mathrm{a} / \mathrm{d}=0.54]$

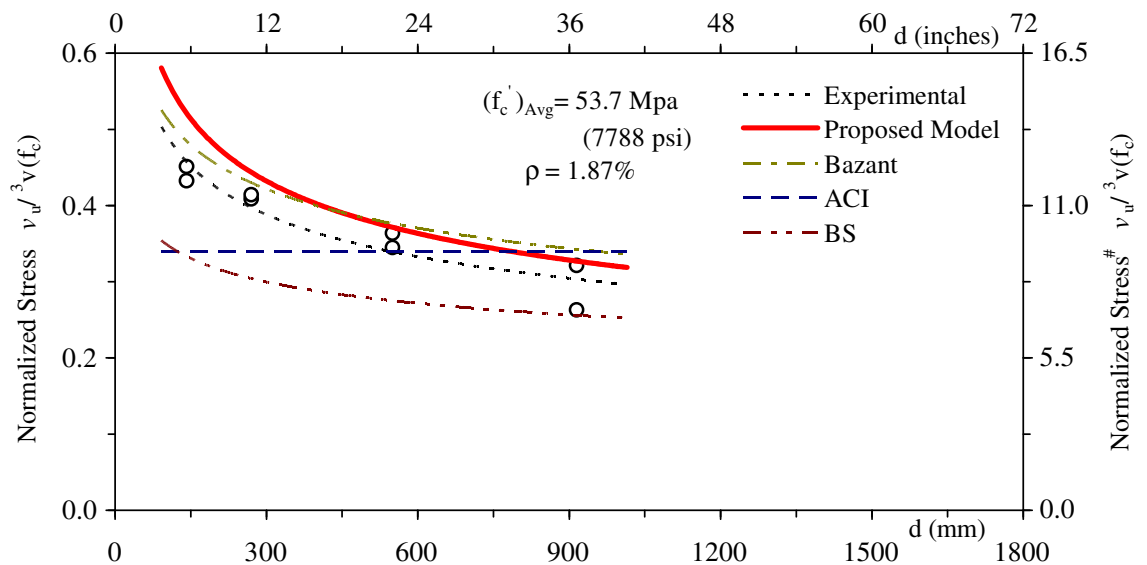

(h) Normalized Stress $v_{\mathrm{u}} /{ }^{3} \mathbf{v}\left(\mathrm{f}_{\mathrm{c}}\right)$ v/s depth KIM-PARK ${ }^{29}[\mathrm{a} / \mathrm{d}=3.0]$

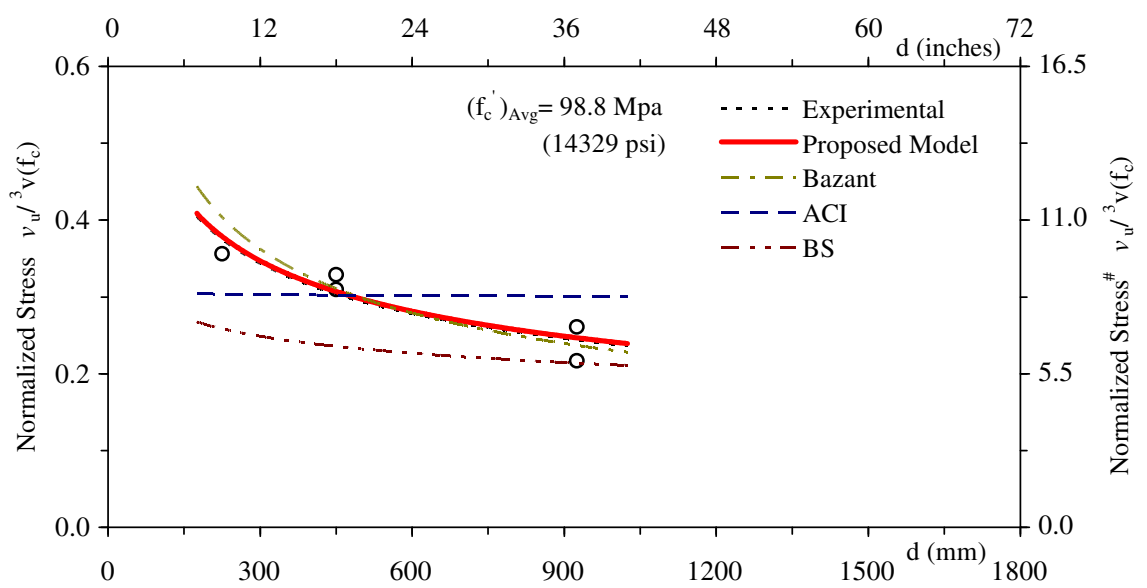

(i) Normalized Stress $v_{\mathrm{u}} /^{3} \mathbf{v}\left(\mathrm{f}_{\mathrm{c}}\right) \mathbf{v} / \mathrm{s}$ depth COLLINS-KUCHMA ${ }^{15}[\mathrm{a} / \mathrm{d}=\mathbf{2 . 9 7}]$

Figure 1. (continued). 
Table 2. Root mean square error for ultimate and diagonal cracking strength.

\begin{tabular}{|c|c|c|c|c|c|c|}
\hline \multirow[t]{2}{*}{ Authors } & \multirow[t]{2}{*}{$\mathrm{a} / \mathrm{d}$} & \multicolumn{3}{|c|}{ Ultimate strength } & \multicolumn{2}{|c|}{ Cracking strength } \\
\hline & & $\begin{array}{c}\text { Proposed } \\
\text { model }\end{array}$ & Bazant-Sun & $\overline{\mathrm{ACI}}$ & $\begin{array}{c}\text { Proposed } \\
\text { model }\end{array}$ & Niwa et al \\
\hline \multirow[t]{9}{*}{ Kani 1967} & 1.00 & 0.53 & $0.66^{*}$ & 1.99 & - & - \\
\hline & 2.00 & 0.11 & 0.12 & 0.55 & - & - \\
\hline & 2.50 & $0.06^{*}$ & $0.07^{*}$ & 0.26 & - & - \\
\hline & 3.00 & $0.05^{*}$ & $0.03^{*}$ & 0.17 & - & - \\
\hline & 4.00 & 0.02 & 0.02 & 0.12 & - & - \\
\hline & 5.00 & 0.03 & 0.04 & 0.14 & - & - \\
\hline & 6.00 & 0.07 & 0.04 & 0.14 & - & - \\
\hline & 7.00 & 0.07 & 0.04 & 0.05 & - & \\
\hline & 8.00 & 0.06 & 0.04 & 0.02 & - & - \\
\hline Taylor 1972 & 3.00 & 0.03 & 0.03 & 0.08 & - & - \\
\hline Bazant \& Kazemi 1991 & 3.00 & $0.11^{*}$ & $0.07^{*}$ & 0.15 & - & - \\
\hline \multirow[t]{3}{*}{ Tan \& Lu 1999} & 0.56 & $0.52 *$ & $4.04^{*}$ & 1.80 & 0.05 & 0.10 \\
\hline & 0.84 & 0.62 & $0.67^{*}$ & 1.60 & $0.09^{*}$ & $0.09^{*}$ \\
\hline & 1.13 & 0.72 & 0.54 & 1.39 & 0.11 & 0.12 \\
\hline \multirow[t]{2}{*}{ Walraven \& Lehwalter 1994} & 1.0 & $0.09^{*}$ & $0.54^{*}$ & 0.75 & 0.06 & 0.09 \\
\hline & 3.00 & 0.02 & 0.03 & 0.08 & - & - \\
\hline Chana 1987 & 3.00 & $0.05^{*}$ & $0.03^{*}$ & 0.13 & - & - \\
\hline \multirow[t]{4}{*}{ Collins \& Kuchma 1999} & 3.00 & 0.02 & 0.02 & 0.06 & - & - \\
\hline & 2.92 & 0.03 & 0.03 & 0.05 & - & - \\
\hline & 3.00 & 0.07 & 0.10 & 0.10 & - & - \\
\hline & 3.00 & $0.07^{*}$ & $0.07^{*}$ & 0.12 & - & - \\
\hline \multirow[t]{4}{*}{ Yang et al 2003} & 0.54 & $0.40^{*}$ & $2.56^{*}$ & 1.17 & 0.07 & 0.16 \\
\hline & 1.1 & 0.44 & 0.37 & 0.90 & 0.21 & 0.17 \\
\hline & 0.54 & 0.38 & $1.08^{*}$ & 1.52 & 0.08 & 0.19 \\
\hline & 1.1 & 0.65 & 0.68 & 1.07 & 0.34 & 0.30 \\
\hline \multirow[t]{2}{*}{ Kim \& Park 1994} & 3.00 & $0.05^{*}$ & $0.04^{*}$ & 0.07 & - & - \\
\hline & 4.56 & 0.16 & 0.17 & 0.44 & - & - \\
\hline \multirow[t]{2}{*}{ Kotosovos 2001} & 3.00 & 0.03 & 0.08 & 0.18 & - & - \\
\hline & 3.00 & 0.03 & 0.04 & 0.08 & - & - \\
\hline \multirow[t]{2}{*}{ Bhal (Bazant et al 1987) } & 3.00 & 0.03 & 0.03 & 0.07 & - & - \\
\hline & 3.00 & $0.03 *$ & $0.04^{*}$ & 0.06 & - & - \\
\hline \multirow[t]{2}{*}{ Leonhardt (Bazant \& Sun 1987) } & 3.00 & 0.04 & 0.05 & 0.09 & - & - \\
\hline & 3.00 & 0.03 & 0.08 & 0.20 & - & - \\
\hline
\end{tabular}

* Indicates that the experimental values are overestimated by a model. The blank space indicates that the tests were performed only for the limited parameters

The size effect on the diagonal cracking strength of RC beams observed by Walraven \& Lehwalter (1994) and Yang et al (2003) are shown in figures 3a, b and d. About 43\% decrease on the diagonal cracking strength is observed in figure $3 \mathrm{~d}$ against $49 \%$ on the ultimate shear strength, as shown in figure $1 \mathrm{~b}$. The ratio $\left(v_{c r} /{ }^{\beta} \sqrt{ } \mathrm{f}_{\mathrm{c}}^{\prime}\right)$ test varies with $\mathrm{d}^{-0.3}$ and the ratio $\left(v_{u} \beta \sqrt{ } \mathrm{f}_{\mathrm{c}}^{\prime}\right)_{\text {test }}$ varies with $\mathrm{d}^{-0.42}$. This shows that the size effect on the diagonal cracking strength is not negligible. In the ACI code, the comment about the size effect on the shear strength of $\mathrm{RC}$ beams is made, but not incorporated in the design models. According to the ACI code, the shear strength of RC beams is overestimated on the large size beams at small percentages of the 


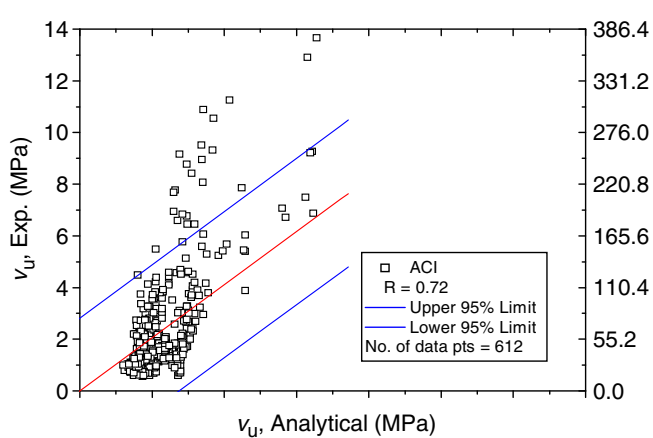

(a)

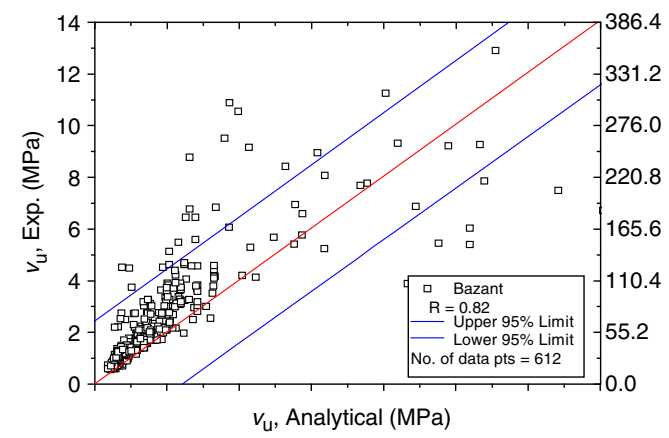

(c)

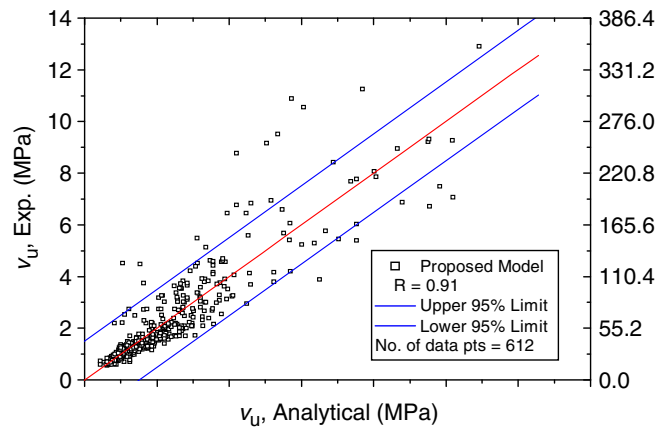

(b)

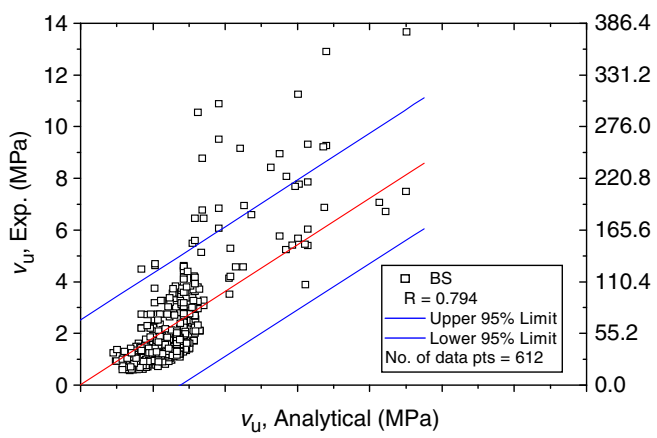

(d)

Figure 2. Ultimate shear strength - measured versus calculated values.

longitudinal reinforcement as shown in figures $1 \mathrm{~d}$, e and $\mathrm{i}$. The shear strength predicted by the ACI code for the a/d ratios, $1<\mathrm{a} / \mathrm{d}<2.5$, are very conservative. The beam depths beyond which the ultimate strengths are overestimated by the ACI code, Eq. 6 are shown in table 3 . The safety margins estimated by the ACI code without the size effect factor are non-uniform on different sizes with the same concrete, longitudinal reinforcement and a/d ratio.

The diagonal cracking strength with the beam depth estimated from Eq. 3 correlates well with the experimental observations on the normal beams. However, the ultimate strength of the beams with a/d $<2.5$ is underestimated. Thus, Eq. 3 is in good agreement with the experimental observations on the normal beams $(\mathrm{a} / \mathrm{d}>2.5)$. The RMSE is small on the proposed model than that of Eq. 3. The measured cracking strength is compared with the calculated values as per the refined model, in Eq. 9, and Eq. 3, also showed in figures 4a-b. The correlation coefficient for the refined model is 0.85 , which is slightly higher than 0.82 for Eq. 3 with better correlation. The data on large size beams is very limited. Due to this there exists a slight deviation of predicted strength from the experimental findings from the reported results.

The century-old conventional strength theory does not explain the reasons for the size effect and the catastrophic mechanism associated with the diagonal failure. Though it is very complex to explain, several theories have been proposed for explaining such mechanisms through fracture mechanics of concrete. It was reported (So \& Karihaloo 1993) that the ultimate shear strength could be calculated by adding the contributions from the tension-softening effect of cracked concrete and the bond of reinforcement. However, the complex shear mechanism is influenced by 


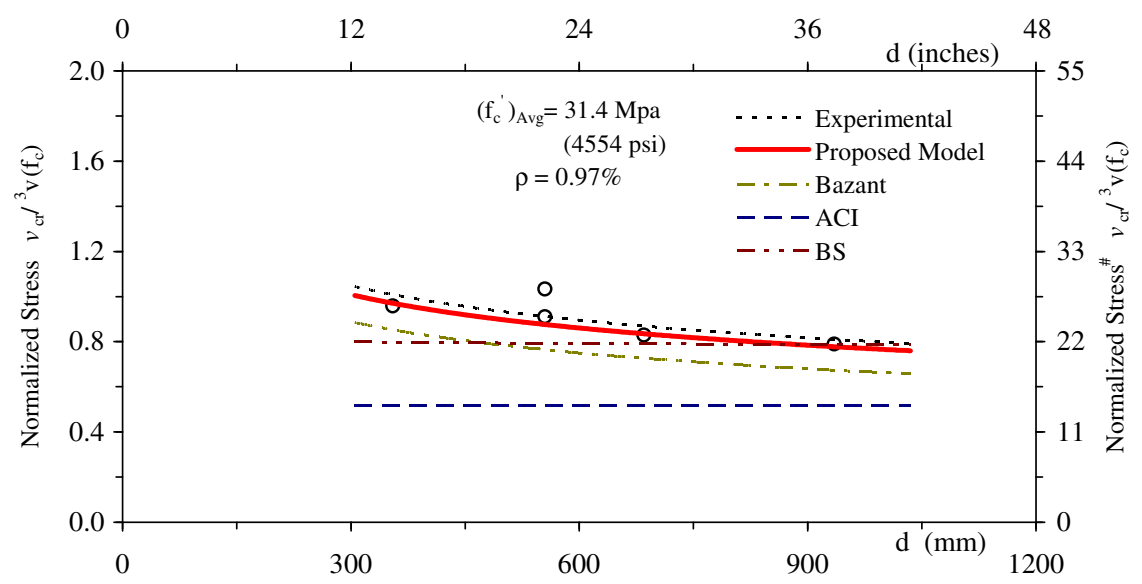

(a) Normalized Stress $v_{\mathrm{cr}} /{ }^{3} \mathbf{v}\left(\mathbf{f}_{\mathrm{c}}\right) \mathrm{v} / \mathrm{s}$ depth YANG et al. ${ }^{17}[\mathrm{a} / \mathrm{d}=0.54]$

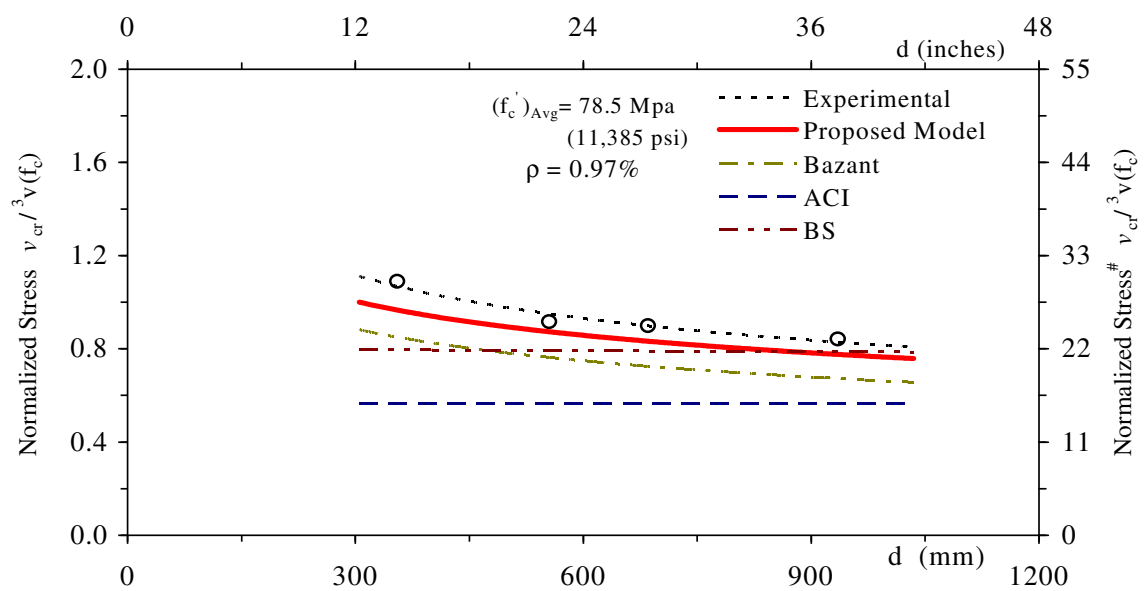

(b) Normalized Stress $v_{\text {cr }} /{ }^{3} \mathbf{v}\left(f_{c}\right) v / s$ depth YANG et al. ${ }^{17}[\mathrm{a} / \mathrm{d}=0.54]$

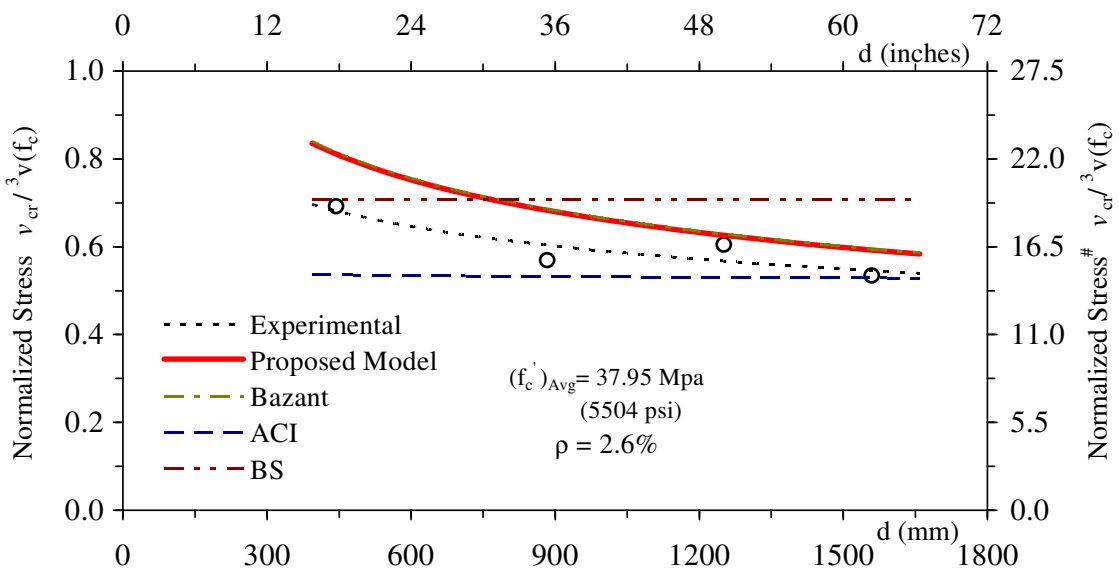

(c) Normalized Stress $v_{\text {cr }} /{ }^{3} \mathbf{v}\left(\mathbf{f}_{\mathrm{c}}\right) \mathrm{v} / \mathrm{s}$ depth TAN-LU ${ }^{12}[\mathrm{a} / \mathrm{d}=\mathbf{0 . 8 4}]$

Figure 3. Comparison of $v_{c r} / 3 \sqrt{ } \mathrm{f}_{\mathrm{c}}$ with depth. 


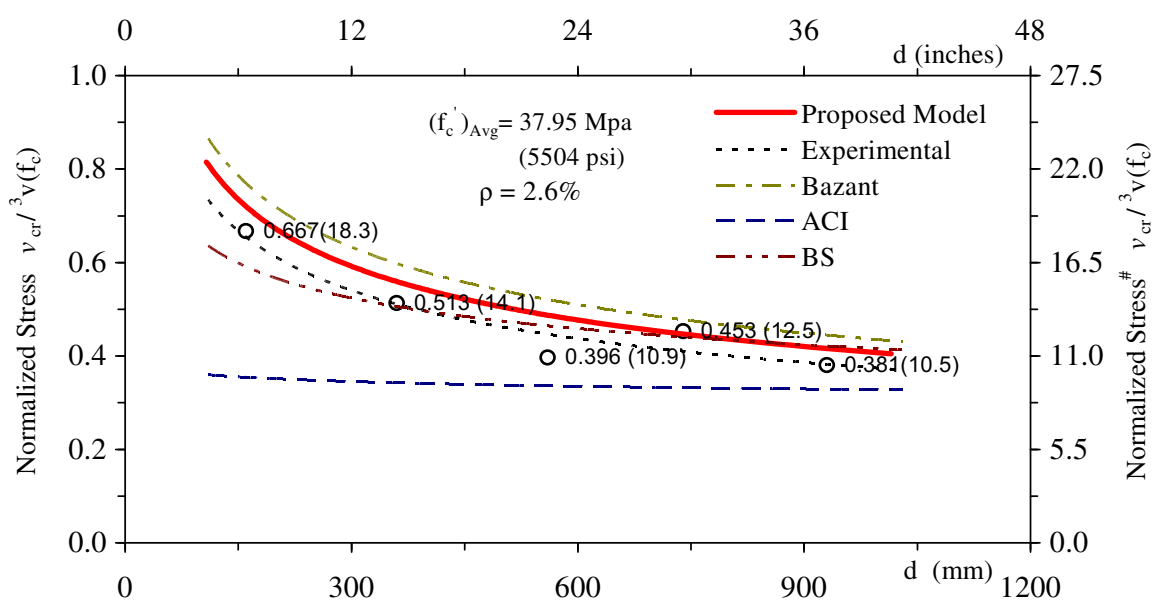

(d) Normalized Stress $v_{\text {cr }} / /^{3} v\left(f_{c}\right)$ v/s depth WALRAVEN ${ }^{13}[a / d=1.0]$

Figure 3. (continued).

the type of concrete, maximum size of coarse aggregate, surface characteristics of aggregate, fracture energy, brittleness and tensile strength of concrete. Fracture mechanics of concrete can explain the variation of brittleness with strength and size of the member. The brittleness of concrete increases with increase in strength and the size of the member (Appa Rao 2001, Appa Rao \& Raghu Prasad 2002). Therefore, the large size beams made up of high strength concrete exhibit high brittleness. The fracture properties of concrete such as stress-crack opening displacement response, fracture energy, tensile strength and hence the brittleness number can vary the behaviour and strength of RC deep beams. The size of fracture process zone associated with the tension-softening response as discussed by So \& Karihaloo (1993) could explain the reasons for the size effect and decrease in the shear strength with increase in the beam depth. In the large size beams, the fracture process zone is small relative to its size, whereas in small size beams, the fracture process zone is relatively large. A significant amount of nonlinear fracture energy is dissipated in the fracture process zone, due to which the small size beams fail at high stress

Table 3. Limiting depth beyond which the shear strength is overestimated by ACI.

\begin{tabular}{llllr}
\hline Authors & $\mathrm{a} / \mathrm{d}$ & $\rho \%$ & $\mathrm{f}_{\mathrm{c}}{ }_{\mathrm{c}}, \mathrm{Mpa}$ & Depth, mm \\
\hline Kani 1967 & 4.0 & 2.76 & 26.7 & 1134 \\
Kani 1967 & 5.0 & 2.8 & 25.9 & 912 \\
Taylor 1972 & 3.0 & 1.35 & 27.8 & 773 \\
Collins \& Kuchma 1999 & 2.97 & 1.13 & 98.8 & 460 \\
Kim \& Park 1994 & 3.0 & 1.87 & 53.7 & 545 \\
Kotosovos 2001 & 3.0 & 1.62 & 38 & 490 \\
& & 1.34 & 40 & 585 \\
Leonhardt & 3.0 & 1.66 & 35.7 & 555 \\
$\quad$ (Bazant \& Sun 1987) & & 1.33 & 37.7 & 915 \\
\hline
\end{tabular}




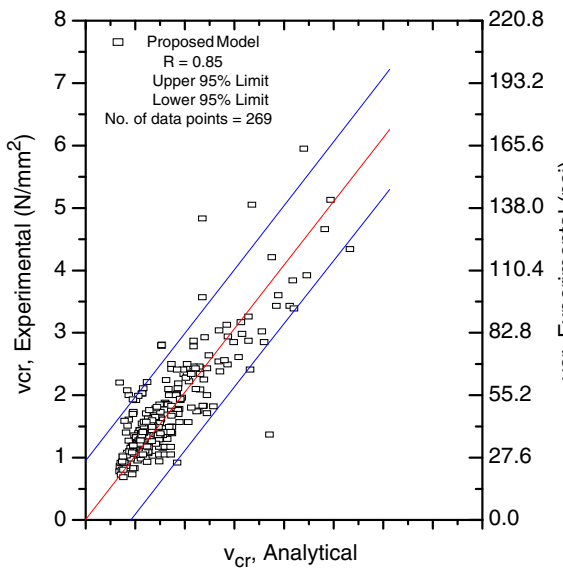

(a)

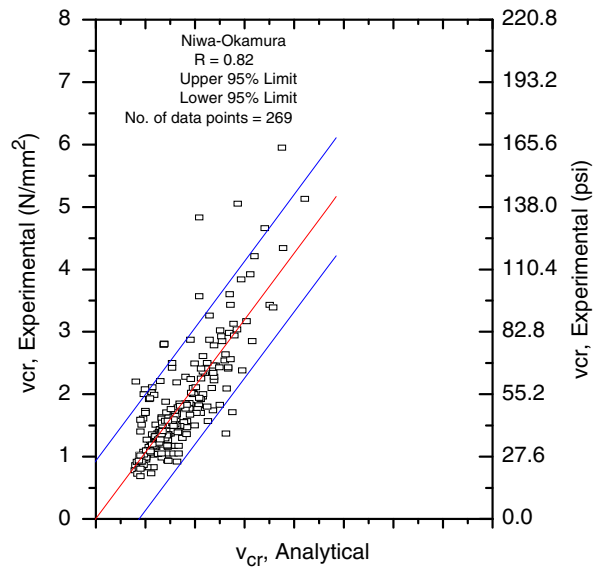

(b)

Figure 4. Diagonal cracking strength - measured versus calculated values.

levels. In the large size beams, the brittleness increases with relatively less energy dissipation in the process zone. Hence, the failure stress decreases with increase in the beam size. The shear span-to-depth ratio and the boundary conditions play a significant role on the shear strength of $\mathrm{RC}$ deep beams. In addition to the above, the interaction of adjacent reinforcement bars, the quality of bond due to type of interface formed in concrete and the ability of reinforcing bars to resist slippage would be reduced due to interaction of the cylindrical failure surfaces due to bond mechanisms, effect of casting depth of concrete in large size beams, bar size, embedment length, clear concrete cover, number of reinforcing bars and the type of anchorage provided influence the ultimate shear strength of RC deep beams (Appa Rao et al 2010). Further, variation of shear mechanisms and extent of their contribution are very important in explaining the size effect on the shear strength of RC beams. The shear strength of uncracked concrete and aggregate internal friction between the aggregate interfaces, and the dowel action of longitudinal reinforcement are also influencing the shear strength. Improved shear strength prediction may be ensured by considering dowel action and aggregate interlock in the calculation.

\section{Conclusions}

Based on the present investigations, the following conclusions have been drawn:

(i) The model proposed to predict the ultimate shear strength is simple and predicts the shear strength of RC beams with a fair degree of accuracy on the deep, short and normal beams for a wide range of values of the influencing parameters.

(ii) It is appropriate to design the RC beams in shear based on the ultimate shear strength to achieve uniform safety margins on different beam depths rather than on the diagonal cracking strength.

(iii) The size effect is more pronounced on the ultimate shear strength. However, the size effect on the diagonal cracking strength is not negligible. 
(iv) The estimated shear strength of RC beams by the ACI code provisions seems to be conservative, which does not incorporate the size effect on the design of RC beams.

\section{Notation}

$A_{s}=$ area of tension reinforcement

$f_{\mathrm{c}}^{\prime}=$ cylindrical compressive strength in $\mathrm{MPa}$

$f_{c u}=$ characteristic strength of concrete cube, $\mathrm{MPa}$

$\rho=$ longitudinal reinforcement ratio

$a=$ shear span

$d=$ effective depth in $\mathrm{mm}$

$a / d=$ shear span-to-depth ratio

$e=$ eccentricity of load

$h=$ overall depth of member

$d_{a}=$ maximum aggregate size

$M_{u}=$ factored moment occurring simultaneously with $\mathrm{V}_{u}$ at critical section

$V_{u}=$ factored shear force at the critical section

$\mathrm{v}_{u}=$ ultimate shear strength

$\mathrm{v}_{c r}=$ diagonal cracking strength

$\gamma_{m}=$ partial safety factor

Appendix I. Details of test data from literature.

\begin{tabular}{|c|c|c|c|c|c|c|}
\hline \multirow[b]{2}{*}{ Authors } & \multirow[b]{2}{*}{$\mathrm{a} / \mathrm{d}$} & \multirow[b]{2}{*}{ Depth, mm } & \multirow[b]{2}{*}{$\rho(\%)$} & \multirow[b]{2}{*}{$\mathrm{f}_{\mathrm{c}}, \mathrm{N} / \mathrm{mm}^{2}$} & \multicolumn{2}{|c|}{ No of beams } \\
\hline & & & & & $\begin{array}{l}\text { Ultimate } \\
\text { strength }\end{array}$ & $\begin{array}{l}\text { Diagonal } \\
\text { cracking }\end{array}$ \\
\hline Clark 1951 & $1.16-2.32$ & 393.7 & 0.98 & $21.5-26.2$ & 12 & 12 \\
\hline \multirow[t]{2}{*}{ Kani 1967,1966 } & $1.0-8.0$ & $132-1097$ & $2.55-2.87$ & $24.8-30.8$ & 44 & \\
\hline & $0.98-5.0$ & $264-287$ & $0.5,0.76,1.8$ & $15.4-36.4$ & 77 & \\
\hline Taylor 1972 & 3.0 & 139-930 & 1.35 & $20.8-32.1$ & 15 & - \\
\hline Bazant \& Kim 1984 & 3.0 & $40.6-165.1$ & 1.64 & 46.5 & 18 & - \\
\hline Tan \& Lu 1999 & $0.56-1.13$ & $444-1559$ & 2.6 & $30.8-49.1$ & 12 & 12 \\
\hline Walraven \& & 1.0 & $160-930$ & $1.08-1.52$ & $18.1-20$ & 5 & 5 \\
\hline Lehwalter 1994 & 3.0 & $125-720$ & $0.74-0.83$ & $34.2-34.8$ & 3 & - \\
\hline Chana 1987 & 3.0 & $106-356$ & $1.73-1.78$ & $24.7-39.5$ & 19 & - \\
\hline Collins \& & $2.92-3.07$ & $110-925$ & $0.76-0.91$ & 37.2 & 4 & - \\
\hline \multirow[t]{3}{*}{ Kuchma 1999} & $2.92-3.0$ & $225-925$ & $0.76-1.01$ & $98.0-98.8$ & 5 & - \\
\hline & 2.92 & $225.0-925$ & $1.05-1.31$ & $36.0-39.0$ & 5 & - \\
\hline & 2.92 & $225-925$ & $0.5-1.31$ & $36.0-94.0$ & 10 & - \\
\hline Yang et al 2003 & $0.53-1.13$ & $355-935$ & $0.9-1.0$ & $31.4-78.5$ & 21 & 21 \\
\hline \multirow[t]{2}{*}{ Kim \& Park 1994} & 3.0 & $142-915$ & $1.01-1.88$ & 53.7 & 10 & - \\
\hline & $4.5-6.0$ & 270 & 1.87 & 53.7 & 10 & - \\
\hline Kotosovos 2001 & 3.0 & $70-600$ & $1.34 \& 1.62$ & $36.1-40$ & 8 & - \\
\hline Ahmad et al 1984 & $1.0-4.0$ & 184-208 & $1.77-6.64$ & $60.8-67$ & 35 & 35 \\
\hline Bresler \& Scrodelis 1963 & $3.97-6.93$ & $254-466$ & $1.03-3.1$ & $16.8-37.6$ & 3 & 3 \\
\hline Cossio \& Siess 1960 & $2.01-6.04$ & $252.5-448.1$ & $1.72-3.61$ & $19.1-36.7$ & 6 & 6 \\
\hline
\end{tabular}


Appendix I. (continued).

\begin{tabular}{|c|c|c|c|c|c|c|}
\hline \multirow[b]{2}{*}{ Authors } & \multirow[b]{2}{*}{$\mathrm{a} / \mathrm{d}$} & \multirow[b]{2}{*}{ Depth, mm } & \multirow[b]{2}{*}{$\rho(\%)$} & \multirow[b]{2}{*}{$\mathrm{f}_{\mathrm{c}}, \mathrm{N} / \mathrm{mm}^{2}$} & \multicolumn{2}{|c|}{ No of beams } \\
\hline & & & & & $\begin{array}{l}\text { Ultimate } \\
\text { strength }\end{array}$ & $\begin{array}{l}\text { Diagonal } \\
\text { cracking }\end{array}$ \\
\hline Elzanty et al 1986 & $2,4 \& 6$ & $266.7-271.8$ & $0.6-3.27$ & $20.7-79.3$ & 15 & - \\
\hline Kim et al 1999 & $2.5,3 \& 4$ & 250 & $1.08 \& 1.94$ & 19.6 & 8 & 8 \\
\hline Krefield \& Thurston 1966 & $2.34-9.74$ & $237.7-482.6$ & $0.8-5.01$ & $12.2-39$ & 78 & 62 \\
\hline Mathey \& Watstein 1963 & 1.51 & 403 & $0.75-3.05$ & $21.9-27$ & 16 & 16 \\
\hline Mattock 1969 & 2.74 & 254 & $1.03-3.1$ & $17.1-46.9$ & 7 & 7 \\
\hline Moody et al 1954 & 1.52 & 533 & $2.7,3.4,4.25$ & 21.9 & 12 & 12 \\
\hline Mphonde et al 1984 & $1.5,2.5,3.6$ & 298 & 3.36 & $20.8-93.7$ & 19 & 19 \\
\hline Pendyala \& Mendis 2000 & $2.0 \& 5.0$ & 140 & 2.0 & $34,63,87$ & 6 & 6 \\
\hline Mohan Rao et al 2004 & 2.35 & 175 & $0.25-3.0$ & 74.5 & 7 & 7 \\
\hline $\begin{array}{l}\text { Rajagopalan \& } \\
\text { Ferguson } 1968\end{array}$ & $3.93-4.22$ & $258.6-268.4$ & $0.25-1.73$ & $23.7-36.5$ & 10 & - \\
\hline Shin et al 1999 & $1.5,2.0,2.5$ & 215 & 3.77 & $52.4,73.1$ & 6 & 6 \\
\hline Taylor \& Brewer 1963 & 3.8 & $220.7-222.3$ & $1.24 \& 1.94$ & $22.4-30.3$ & 12 & - \\
\hline Taylor 1960 & $1.64-4.91$ & 279.4 & 2 & $17.9-18.8$ & 5 & - \\
\hline Van Den Berg 1962 & $2.7-4.2$ & $228.6-300$ & $1.72-4.32$ & $14.2-46.9$ & 32 & 26 \\
\hline Xie et al 1994 & $1-3.0$ & 215.9 & 2.07 & $37.7-98.9$ & 6 & 6 \\
\hline Leonhardt & 3.0 & $70-600$ & $1.33-2.07$ & $28.4-37.7$ & 14 & - \\
\hline (Bazant \& Sun 1987) & $4-8$ & $270-278$ & $2.01-2.07$ & $28.4-31.5$ & 9 & - \\
\hline Bhal (Bazant 1987) & 3.0 & $297-1200$ & $0.59-1.29$ & $22.8-29.1$ & 8 & - \\
\hline \multirow{2}{*}{$\begin{array}{l}\text { Zararis \& } \\
\quad \text { Papadakis 2001) }\end{array}$} & $1.5,2.0,2.5$ & 200 & $0.8-1.2$ & $24-25.3$ & 20 & - \\
\hline & \multicolumn{4}{|c|}{ Total } & 612 & 269 \\
\hline
\end{tabular}

\section{References}

ACI ASCE Committee 3261962 Shear and diagonal tension, J. Am. Concrete Institute, 277-333

ACI 318 M-02 2002 Building code requirements for structural concrete, ACI, Michigan

ACI 3182005 Building code requirements for structural concrete, ACI, Michigan

Ahmad S H, Khaloo A R, Poveda A 1984 Shear capacity of reinforced HSC beams, ACI J., 83(2): 297-305

Appa Rao G 2001 Nonlinear fracture and size effect in high strength and high performance concretean experimental approach, A Ph.D. Thesis submitted to the Department of Civil Engineering, Indian Institute of Science, Bangalore

Appa Rao G, Raghu Prasad B K 2002 Fracture energy and softening behavior of high-strength concrete, Cement and Concrete Res., 32: 247-252

Appa Rao G, Faiz Sulthana, Pandurangan K 2010 Studies on bond strength of reinforced concrete, J. Struct. Eng., 36(5): 347-353

ASCE-ACI Com 4451998 Recent approaches to shear design of structural concrete, J. Struct. Eng., 24(2): 1374-1417

Bazant Z P, Kazemi M T 1991 Size effect on diagonal shear failure of beams without stirrups, ACI Structural Journal, 88(3): 268-276

Bazant Z P, Kim J K 1984 Size effect in shear failure of longitudinally reinforced beams, Proceedings, ACI Structural Journal, 81(5): 456-468

Bazant Z P, Sun H H 1987 Size effect in diagonal shear failure: influence of aggregate size and stirrups, ACI Materials Journal, 84(4): 259-272 
Bresler B, MacGregor J G 1967 Review of concrete beams failing in shear. J. Struct. Division, Proc. American Society Civil Eng., 343-371

Bresler B, Scrodelis AC 1963 Shear strength of RC beams, Proc. ACI J., 60(1): 51-74

BS 8110-1 1997 Structural use of concrete, Part 1: Code of Practice for Design and Construction, British Standards Institution, London

Chana P S 1987 Investigation of the mechanism of shear failure of reinforced concrete beams, Magazine of Concrete Research, 39(141): 196-204

Clark A P 1951 Diagonal tension in RC beams. ACI J., 23(2): 145-156

Collins M P, Kuchma D 1999 How safe are our large, lightly reinforced concrete beams, slabs and footings, ACI Structural Journal, 96(4): 482-490

Cossio R D D, Siess C P 1960 Behaviour and shear of beams and frames without web reinforcement, Proc ACI J., 56(9): 695-735

CSA 1994 Design of concrete structures, CSA A23.3. Rexdale, Ontario, pp 199

Elzanty A H, Nilson A H, Slate F O 1986 Shear capacity of reinforced concrete beams using high strength concrete, ACI J., 83(2): 290-296

JSCE 1986 Standard specification for design and construction of concrete structures, Part I (Design), 1st $\mathrm{Ed}$, Referred in shear strength of reinforced concrete beams without transverse reinforcement $\mathrm{M}$ Khuntia and B Stojadinovic (eds) ACI Structural Journal, Sept-Oct. 2001, pp 648-656

Kani G N J 1966 The basic facts concerning shear failure, Proc. ACI J., 63(7): 675-692

Kani G N J 1967 How safe are our large reinforced concrete beams? ACI J., 64(3): 128-141

Karihaloo B L 1995 Fracture mechanics and structural concrete, pp. 152, Longman group Ltd.

Kim J K, Park Y D 1994 Shear strength of reinforced high strength concrete beams without web reinforcement, Magazine of Concrete Research, 46(166): 7-16

Kim D, Kim W, White R M 1999 Arch action in reinforced concrete beams- a rational prediction of shear strength. ACI Struct. J., 96(4): 586-593

Kong F K, Garcia R C, Paine J M, Wong H H A, Tang C W J, Chemrouk M 1986 Strength and stability of slender conc deep beams, St Eng., 64B(3): 173-180

Kotosovos M D 2001 On the size effect phenomenon in concrete structures, fracture mechanics of concrete structures, de Borst et al (eds), 705-711

Krefeld W J, Thurston C W 1966 Studies of the shear and diagonal tension strength of simply supported reinforced concrete beams, ACI J., 63(4): 451-476

Maekawa K, Pimanmas A, Okamura H 2003 Non linear mechanics of reinforced concrete. London and New York: Spon Press, pp. 74

Mathey R G, Watstein D 1963 Shear strength of beams without web reinforcement containing deformed bars of different yield strengths, ACI J., 60(2): 183-208

Mattock A H 1969 Diagonal tension cracking in concrete beams with axial forces, Proc ASCE, 95(ST9): 1887-1900

Moody K G, Viest I M, Elstner R C, Hognestad E 1954 Shear strength of reinforced concrete beams, Part-1: tests of simple beams. ACI J., 51(3): 317-332

Mphonde A G, Frantz G C 1984 Shear tests of high and low strength concrete beams without stirrups, Proc. ACI J., 81(4): 350-357

Niwa J, Yamada K, Yokozawa K, Okamura H 1987 Revaluation of the equation for shear strength of reinforced concrete beams without web reinforcement, Concrete Library of JSCE, 9: 65-84

Pendyala R S, Mendis P 2000 Experimental study on shear strength of high strength concrete beams, ACI Structural Journal, 97(4): 564-571

Rajagopalan K S, Ferguson Phil M 1968 Exploratory shear tests emphasizing percentage of longitudinal steel, Proc ACI J., 65(9): 634-638

Rama Mohan Rao P, Krishnamoorthy T S, Gopalakrisnan S 2004 Shear strength of high performance concrete beams, Proc of Intl Conf on Ads in Con and Constn, Hyd, India, 277-290

Shin S W, Lee K S, Moon J I, Ghosh S K 1999 Shear strength of Re. HSC beams with shear span to depth ratios between 1.5 and 2.5., ACI Struct. J., 96(4): 549-556

So K O, Karihaloo B L 1993 Shear capacity of longitudinally reinforced beams - a fracture mechanics approach, ACI Struct. Journal, 90(7): 591-600 
Tan K H, Lu H Y 1999 Shear behaviour of large reinforced concrete deep beams and code comparisons, ACI Structural Journal, 96(5): 836-845

Taylor R 1960 Some shear tests on reinforced concrete beams without shear reinforcement, Magazine of Concrete Research, 12(36): 145-154

Taylor H P J 1972 Shear strength of large beams, ASCE, 98(ST11): 2473-2490

Taylor R, Brewer R S 1963 The effect of the type of aggregate on the diagonal cracking strength of reinforced concrete beams, Magazine of Concrete Res., 15(44): 87-92

Van Den Berg F J 1962 Shear strength of RC beams without web reinforcement, Part-2 - factors affecting load at diagonal cracking, ACI J., 59(11): 1587-1600

Walraven J, Lehwalter N 1994 Size effects in short beams loaded in shear, ACI Struct. Journal, 91(5): $585-593$

Xie Y, Ahmad S H, Yu T, Hino S, Chung W 1994 Shear ductility of RC beams of normal and high strength concrete, ACI Struct. J., 91(2): 140-149

Yang K H, Chung H S, Lee E T, Eun H C 2003 Shear characteristics of HSC deep beams without shear reinforcements, Eng. Struct., 25: 1343-1352

Zararis P D, Papadakis G Ch 2001 Diagonal shear failure and size effect in RC beams without web reinforcement, Journal of Structural Eng., 127(8): 733-742

Zsutty T C 1968 Beam shear strength prediction by analysis of existing data, Proc. ACI J., 65(11): 943-951. 